\title{
КОНВЕРГЕНТНІСТЬ ОСВІТНІХ ПРОЦЕСІВ ЄВРОПЕЙСЬКОЇ ІНТЕГРАЦІЇ ЯК ОСНОВА УСПІШНОСТІ ІНТЕГРАЦІї ПРОСТОРОВО-ЕКОНОМІЧНИХ СИСТЕМ
}

\author{
CONVERGENCE OF EDUCATIONAL PROCESSES \\ OF EUROPEAN INTEGRATION AS THE BASIS OF SUCCESS \\ OF INTEGRATION OF SPATIAL AND ECONOMIC SYSTEMS
}

\begin{abstract}
Автором зазначені першочергові завдання української освіти. Зазначено, що ефрективність інтеграційних процесів безпосередньо пов'язана зі стабільністю і передбачуваністю зовнішньої та внутрішньої політики. Відзначено, що у процесі євроінтеграції різних педагогічних систем у єдиний освітянський простір важливим $є$ конвергентний аналіз цих систем. Охарактеризовано конвергенцію в освіті як стабілізаційний чинник, що сприяє відбору оптимальних компонентів, перевірених у прочесі тривалої освітньої практики. Зазначено, що конвергенція освітньої політики $є$ побічним продуктом економічної та соціальної політики. Охарактеризовано особливості інноваційних методологічних досліджень конвергентності освітніх прочесів. Відзначено, що система освіти передає фрактичні знання новому поколінню, але недостатньо дає знань, необхідних для просресійного самовизначення. Вказано, що наступний крок у фрормуванні конвергентної освіти пов'язаний із понят тям трансдисциплінарності, яка передбачає синкретичне осмислення результатів різних науково-дослідних практик на більш високому концептуальному рівні. Зазначено базові компоненти методології конвергентної освіти та ії принципи. Охарактеризовано вирішення завдань, на які має бути спрямоване управління системи освіти в умовах європейської конвергенції. Відзначено, що практичний досвід конвергенції фрормальної освіти студентів дозволяє констатувати спрямованість діяльності просресорсько-викладацького складу на вдосконалення підготовки. Розглянуто види конвергенції в контексті ї реалізації на різних рівнях. Зазначено, що результатом конвергенції $є$ еволюційний розвиток інфрормаційно-освітнього середовища в напрямі інтеграції різних освітніх платорорм, сервісів і технологій. Охарактеризовано умови, яких потрібно дотримуватися у процесі впровадження сучасного управління в закладах вищої освіти. Вказано, що конвергентна стратегія профресійної підготовки стає можливою за умови поєднання нормативної організації освітнього процесу й ініціативної освітньої діяльності студентів. Ключові слова: конвергентність, освітня послуга, євроінтеграція, фрілософрія освіти, просторово-економічна система.
\end{abstract}

The author mentions the priority tasks of Ukrainian education. It is noted that the effectiveness of integration processes is directly related to the stability and predictability of external and internal policy. It is noted that in the process of European integration of different pedagogical systems into a single educational space, a convergent analysis of these systems is important. Convergence in education is characterized as a stabilizing factor that contributes to the selection of optimal components tested in the process of long-term educational practice. It is noted that the convergence of educational policy is a by-product of economic and social policy. Features of innovative methodological researches of convergence of educational processes are characterized. It is noted that the education system transmits actual knowledge to the new generation, but does not provide enough knowledge necessary for professional self-determination. It is stated that the next step in the formation of convergent education is related to the concept of transdisciplinarity, which involves syncretic understanding of the results of various research practices at a higher conceptual level. The basic components of the methodology of convergent education and its principles are indicated. The solution of the tasks to which the management of the education system in the conditions of European convergence should be directed is characterized. It is noted that the practical experience of convergence of formal education of students allows stating the orientation of the teaching staff to the improvement. The types of convergence in the context of their implementation at different levels are considered. It is noted that the result of convergence is the evolutionary development of information and educational environment in the direction of integration of different educational platforms, services and technologies. The conditions that must be observed during the implementation of modern management in higher education institutions are described. It is indicated that the convergent strategy of professional training becomes possible under the condition of combination of normative organization of educational process and initiative educational activity of students.

Key words: convergence, educational service, European integration, philosophy of education, spatial and economic system.
Постановка проблеми в загальному вигляді. Осучаснення підготовки майбутніх фахівців в умовах конвергентності освітніх послуг спрямоване на впровадження найефективніших світових підходів в освітній процес. Конвергенція освіти одна з найважливіших проблем сучасності. Конвергентний підхід трактується як процес стирання міждисциплінарних меж між нау- ковим і технологічним знанням. Подолання цих кордонів дозволяє розширити можливості для здобуття нових знань, потрібних для створення об'єктів, подібних до природних за функціональністю та призначенням. Конвергенція розкриває перспективи здобуття нових знань та ідей із метою нових відкриттів, що можуть вплинути на всі сфери життя людини. 
Аналіз останніх досліджень і публікацій. За останні роки здійснено багато досліджень, опубліковано наукові праці багатьох учених у цьому напрямі, серед яких І.Ю. Алексєєва [1], М.В. Деєв, А.Г. Кравець, А.Г. Фіногеєв [2], Л.В. Денисюк [3], С.А. Вавренюк [4], А.В. Лубський [5], С.М. Писаренко [6], Н.В. Сулаєва [7], І.О. Ахновська [8], Т.С. Фещенко, Л.А. Шестакова [9], M.S. Bainbridge, M.C. Roco [11].

Виділення не вирішених раніше частин загальної проблеми. Критичний підхід до конвергентності в галузі освіти характерний для всіх країн світу, формує базові вимоги до освіти - збереження і збагачення людських цінностей. Спрямованість освіти, процесу навчання тільки на накопичення знань та інформації не виправдовує себе. Конвергентність досліджено досить поверхнево, тому важливо розглядати досліджуване явище більш детально в розрізі сучасних освітніх тенденції в Україні та світі.

Мета статті - проаналізувати конвергентність освітніх процесів європейської інтеграції як основу успішності інтеграції просторово-економічних систем.

Виклад основного матеріалу. В умовах радикальних соціально-економічних перетворень відбулися зміни, які зумовили становлення та розвиток ринку освітніх послуг у країні. Унаслідок процесів глобалізації, європейської інтеграції й інформаційної революції відбуваються трансформаційні зрушення в національній системі освіти, наближення до принципів Болонського процесу. Натепер першочерговим завданням української освіти $€$ якнайшвидша адаптація до єдиних європейських освітянських критеріїв і стандартів. Обрані шляхи модернізації освіти України співзвучні загальноєвропейським і євроатлантичним підходам, що сприяє ефективній реалізації основної мети державної політики в галузі освіти, а саме: створення умов для розвитку особистості і творчої самореалізації кожного громадянина України, оновлення змісту освіти й організації освітнього процесу відповідно до демократичних цінностей, ринкових засад економіки, сучасних науково-технічних досягнень.

Аналіз впливу цифровізації економіки на соціально-економічний розвиток приводить до розуміння необхідності вирішення суспільством таких завдань: збереження зайнятості населення за збільшення продуктивності праці. Це не тільки перерозподіл працюючих в інші галузі, а й нове розуміння самої суті виконуваної роботи і відповідна підготовка фахівців для реального сектора економіки (наприклад, замість виточування деталей сучасний робіт- ник повинен уміти програмувати, щоби працювати на верстатах із числовим програмним управлінням); підвищення якості життя суспільства за збільшення продуктивності праці.

Абсолютно слушно й обґрунтовано вітчизняні науковці зауважують, що ефективність інтеграційних процесів безпосередньо пов'язана з такими двома їхніми головними рисами, як стабільність і передбачуваність зовнішньої та внутрішньої політики, кожна 3 яких має виходити суто з національних інтересів - забезпечення захищеності життєво важливих потреб людини, суспільства й держави, духовного й інтелектуального розвитку особистості, зростання добробуту населення, збалансованості освітніх, наукових та виробничих ресурсів, необхідного рівня інвестицій в інтелектуальну сферу, диверсифікації економічних зв'язків [10].

У процесі євроінтеграції різних педагогічних систем у єдиний освітянський простір важливим є конвергентний аналіз цих систем. Необхідно шукати спільне навіть у разі розбіжностей у сприйнятті і підходах, за різних способів мислення, цілей, цінностей, напрямів подальшого розвитку особистості і педагогічних систем, у яких вона формується [8].

Конвергенція в освіті $€$ стабілізаційним чинником, що сприяє відбору оптимальних компонентів, перевірених у процесі тривалої освітньої практики. Це об'єднує ідеї розроблення та впровадження освітніх стандартів, що гарантують функціональне забезпечення гарантованого мінімуму змісту базових освітніх програм, стандартизацію обсягів навчального навантаження, вимог до фахової підготовки майбутніх спеціалістів. На державному рівні це - гармонізація системи вищої освіти, що передбачає координацію вимог до знань студентів, інтеграція системи вищої освіти до стандартів європейського простору; на регіональному рівні - інформаційна підтримка освітніх заходів для подальшого підвищення рівня освіченості громадян; на рівні освітніх заходів - відкритість до запозичення форм, методів та засобів організації педагогічного процесу.

Конвергенція освітньої політики в цьому разі є побічним продуктом економічної та соціальної політики. Наприклад Європейський Союз, де конвергенція освітніх систем була наслідком гармонізації політичного й економічного життя. Однак конвергенція є не стільки синонімом реформи, хоча часто і використовується в цьому взаємозв'язку. Конвергенція виступає більше причиною реформування. Здійснюються реформи з метою конвергенції національних систем освіти. 
Вивчення конвергентних (високих) технологій передбачає використання широкого спектра методологічних інновацій XXI ст. щодо їх аналізу. Дослідження перспективних напрямів у розвитку сучасної методології показало, що вирішення складних дослідницьких завдань передбачає не лише використання принципово нових методів, але і так само нових стратегій наукового пошуку. Конвергентні мережі, як техніко-технологічні утворення, є індиферентними до віку, статі, фінансових можливостей соціальних суб'єктів. Предметом їхнього «інтересу» є статистичний соціальний зріз у контексті потреб, бажань, пріоритетів, попиту тощо.

Як інноваційні методологічні дослідження конвергентності освітніх процесів було виділено такі:

- глибоке дослідження об'єктів із позицій міждисциплінарного підходу. Цей підхід дав можливість дослідження об'єкта в його цілісності, що передбачає інтеграцію наукових знань та взаємодії наукових дисциплін;

- зміщення парадигми цілісності й інтегративності науки через нові форми взаємозв'язку всіх гілок наукового знання;

- становлення синергетичного підходу, на основі якого відбувається бурхливий процес формування нового понятійного та категоріального апарату.

Конвергенція являє собою не тільки взаємний вплив, але й взаємне проникнення технологій, коли границі між окремими технологіями стираються, а цікаві й неочікувані результати з'являються саме в рамках міждисциплінарної роботи на перетині наук. 3 розвитком конвергенції NBIC-технологій уперше в історії людства спостерігається паралельне прискорення розвитку декількох науково-технічних напрямів, що безпосередньо впливають на суспільство.

Вища освіта має надати можливість ознайомитися з міждисциплінарною ідеологією, міждисциплінарними методами. Система вищої освіти, незважаючи на постійні реформи, усе ж досить інертна. Тому, вочевидь, своїм завданням активісти міждисциплінарного підходу бачать навчання міждисциплінарним навичкам, які, ймовірно, будуть у найближчому майбутньому вкрай затребувані.

Важливо розуміти, що перспектива зростання можливостей розвитку людини передусім вплине на економіку, i, як наслідок, освіту: потрібні освітні практики, орієнтовані на міждисциплінарний підхід, високі технології, випереджальне навчання. Суттєвим є те, що нові підходи у змісті, формах, методах, технологіях навчання повинні реалізовуватися вже на шкільному рівні.
Система освіти в основному передає фактичні знання новому поколінню, але недостатньо дає знань, необхідних для професійного самовизначення. Молоді люди через низку причин (нечітка перспектива, матеріальні труднощі тощо) невпевнено дивляться в майбутнє, не знають відповідей на питання, із чим буде пов'язана їхня професійна діяльність. Додаткова складність - визначити своє професійне майбутнє ще у шкільні роки. Для багатьох випускників не визначено способу їхньої взаємодії зі стрімко мінливим навколишнім світом.

Наступний крок у формуванні конвергентної освіти пов'язаний із поняттям трансдисциплінарності, яка передбачає синкретичне осмислення результатів різних науково-дослідних практик на більш високому концептуальному рівні. Основою такого концептуального осмислення $€$ принцип трансдисциплінарності синкретизму, у рамках якого соціальна реальність розглядається як цілісна впорядкована система, що має емерджентний характер. У такому разі конвергенція породжує цілісну систему знань, яка синкретично узагальнює на метатеоретичному рівні наукові результати, отримані у процесі різних дисциплінарних і міждисциплінарних дослідницьких практик, пов'язаних із вивченням цих сегментів [5].

Методологія конвергенції освіти у світлі НБІКС-технологій може бути визначена як трансдисциплінарність. Виходячи із цього розуміння необхідно вибудовувати програми, процеси та процедури підготовки НБІКСфахівців. Такий підхід дасть можливість виховати цілісного, багатостороннього, багатовимірного фахівця, який вміє знаходити взаємозв'язки в явищах, здатний застосувати знання на практиці й усвідомлює наслідки своїх дій.

Зміни, які властиві сучасній українській системі професійної освіти, усе більше орієнтують її на «вільний розвиток людини», її високу культуру, творчу ініціативу, самостійність, конкурентоспроможність, мобільність майбутніх фахівців. Це вимагає якісно нового підходу до формування майбутнього професіонала. Саме тому ключову роль у новій парадигмі освіти відіграє компетентність як результат навчання. Для вищого професійного закладу освіти це означає, що випускник ЗВО повинен не лише мати низку загальних і професійних компетентностей, які відповідають певному рівню, якості освіти і кваліфікації, але також має бути здатним застосовувати знання, уміння і напрацьований практичний досвід у своїй професійній діяльності. 
Конвергентна освіта - це цілеспрямований процес формування компетенцій, необхідних для життя і трудової діяльності в епоху конвергентних наук і технологій.

Дослідження конвергентних зв'язків в теорії розвитку освітніх процесів доводить, що забезпечення наздоганяючого ефекту суспільними системами можливе за умови наявності «соціального потенціалу» - сприятливих умов та можливостей для розвитку креативного потенціалу особистості. Така ідея пропагується у проєкті Концепції гуманітарного розвитку України на період до 2020 р., де інтелект, освіта, професійний досвід, соціальна мобільність, здатність до креативності й інновацій у професійній діяльності і соціальному житті визнаються головною складовою частиною національного багатства й основним ресурсом соціально-економічного розвитку, запорукою високого креативного потенціалу суспільства. Розвиток креативного потенціалу дозволить абсорбувати нові технології, залучати капітал і брати участь у глобальних ринках, що безпосередньо визначатиме успішність регіону на міжнародній арені.

Методологія конвергентного освіти включає такі компоненти, як:

- взаємодія наукових дисциплін (предметів), передусім природних;

- реалізація міждисциплінарних проєктних і дослідницьких практик;

- взаємопроникнення наук і технологій.

До ключових принципів конвергентної освіти належать:

- міждисциплінарний синтез природничо-наукового (і гуманітарного) знання;

- переорієнтація навчальної діяльності 3 пізнавальної на проєктивно-конструктивну;

- модель пізнання - конструювання;

- мережева комунікація;

- навчання не предметів, а різних видів діяльності;

- надпредметні знання через НБІКСтехнології;

- провідна роль самоорганізації у процесах навчання [9].

І.Ю. Алексєєва вважає, що конвергенція не зводиться до простої інтеграції, до того ж не завжди в ній $є$ потреба, варто говорити про конвергентний розвиток різних областей знання, оскільки «те, що відбувається в одних областях, сприяє усвідомленню питань, актуальних для інших областей, виникненню в цих областях аналогічних методів і підходів» $[1$, c. 9-15].

Спирання на постулати теорії конвергентного розвитку використання освітнього потенціалу як ключового ресурсу соціаль- но-економічного зростання може приводити до виникнення синергетичного ефекту взаємодії суб'єктів господарської діяльності у формі посилення їхньої інноваційної складової частини на основі більш ефективного поширення знань і технологій, підвищувати ефективність комунікаційних процесів. Отже, економічна система може набути нових конкурентних переваг на основі більш стійкого розвитку й ефективного управління ресурсами. Забезпечення реалізації концепції конвергентного розвитку потребуватиме формування якісно нових механізмів стабілізації, пов'язаних із проведенням ефективної економічної та інноваційної політики, з формуванням правильних траєкторій економічної динаміки депресивних регіонів.

Управління системи освіти в умовах європейської конвергенції повинне бути спрямоване на вирішення таких завдань, як [4]:

- організація вільного доступу до здобуття освітніх послуг, рівень яких задовольняє актуальні освітні потреби українського населення;

- забезпечення умов для рівного доступу до здобуття вищої освіти для всіх, хто бажає, на всіх рівнях освітньої системи;

- збільшення якості освітніх послуг та розвиток її відповідно до запиту суспільства;

- підвищення результативності функціонування освітньої системи;

- гарантування безперервності освітнього процесу;

- дотримання принципу безоплатності вищої освіти завдяки персоніфікації фінансування та розподілу бюджетних коштів, що розраховані наа забезпечення освітніх потреб;

- інтегрування закладів вищої освіти різних типів в об'єднання, асоціації;

- розвиток конкурентоспроможного освітнього середовища.

Конвергентні технології задають нову стратегію розвитку цивілізації і в цій якості потребують усебічного осмислення. Вони стають стратегічним напрямом розвитку будь-якої розвиненої країни та визначають ступінь інтегрованості національної системи у глобальний простір, формують якісно нові форми господарських відносин, міжнародного бізнесу, торгівлі тощо. Усе це означає, що сучасна наука розширює свої обрії й збільшує темпи науково-технічного прогресу.

Практичний досвід конвергенції формальної освіти студентів дозволяе констатувати спрямованість діяльності професорсько-викладацького складу на вдосконалення підготовки. Це увиразнюється у впливові на: вдосконалення ключових компетентностей майбутніх фахівців (зокрема, обізнаність та 
самовираження у сфері різних видів ключових компетентностей, спілкування державною мовою тощо) [7].

Водночас компетентнісний підхід передбачає зміну цілей і очікуваних результатів освіти у вигляді компетентностей, які відображають різні рівні професійних завдань. Результат освіти в контексті компетентнісного підходу розглядається як уміння діяти, застосовувати набуті знання у проблемних ситуаціях професійної діяльності.

Конвергенція відбувається там, де наукові дисципліни або ключові технології дозволяють поєднання з іншими дисциплінами або прогресивними технологіями й обіцяють нову додану вартість за межами синергії. Цей широкий опис може одержати подальший розвиток у трьох підкатегоріях, кожна з яких належить до окремої області застосування:

- конвергенція на рівні наукових досліджень: де раніше окремі дисципліни науки та техніки стають взаємопов'язаними у спільному виробництві нової галузі наукових досліджень;

- конвергенція на рівні виробництва та розробки продукції;

- конвергенція у впровадженні технологій у соціально-технічних системах, як-от охорона здоров'я, логістика та гарантування продовольчої безпеки [12, с. 8].

Як бачимо, концепція конвергентних технологій формується навколо двох напрямів. Перший напрям - технологічний - синергетично об'єднує п'ять високих технологій, які приведуть до глобальної трансформації самого способу розвитку людської цивілізації загалом завдяки технологічним інноваціям. Другий - привертає увагу до проблеми «поліпшення людини», «розширення людини».

Конвергенція в освіті може бути реалізована на різних рівнях залежно від сфери застосування, що дозволяє визначити такі її види, як:

- освітньо-технічне злиття у плані зближення і збіжності освітніх технологій, моделей життєвих циклів (ЖЦ) ОП і ЕОР;

- навчально-методична конвергенція у плані зближення і збіжності ОП різних спеціальностей і ЕОР із різних дисциплін;

- професійна конвергенція у плані зближення компетенцій для різних видів професійної діяльності та вимог роботодавців;

- організаційна конвергенція у плані зближення систем управління освітнім контентом (learning content management system LCMS), систем управління навчанням (learning management system - LMS), систем управління навчальною діяльністю (learning activity management system - LAMS);
- когнітивно-креативна конвергенція у плані зближення творчих і когнітивних технологій під час підготовки фахівців для професійної діяльності.

Реалізація в закладах освіти конвергентного підходу в навчанні спрямована на формування такого освітнього середовища, у якому здобувачі освітніх послуг сприймають світ як єдине ціле, а не як перелік окремих дисциплін. Але для організаційно-методичного забезпечення конвергентного підходу, крім спеціальної підготовки педагогів і розроблення навчально-методичних матеріалів, необхідна організація проєктно-дослідницької діяльності. Вирішується це завдання не тільки шляхом нарощування освітніх резервів, але і за допомогою масштабного залучення зовнішніх ресурсів міста. Тому відмітною рисою нового освітнього середовища системи освіти стає глибокий інтеграційний взаємозв'язок закладу освіти, науки і виробництва.

Шлях до конвергенції стандартів вищої освіти полягає у визначенні загальних орієнтирів, недотримання яких свідчить про невідповідність національної системи освіти прогресивній міжнародній практиці. На цьому шляху стоять донорські агентства, які фінансують двосторонні та регіональні програми розвитку етики, цінностей, освіти, які управлінцю потрібно залучити та координувати їхню діяльність.

Результатом конвергенції $€$ еволюційний розвиток інформаційно-освітнього середовища в напрямі інтеграції різних освітніх платформ, сервісів і технологій. Базовою інфраструктурою конвергентного освіти $€$ інтелектуальне освітнє середовище (далі - IOC), яке повинне підтримувати процес безперервного навчання у вигляді цілісного циклу, що передбачає вивчення, дослідження, творчість, аналіз, дискусію, публікацію, проєктну діяльність тощо [2].

Важливою умовою конвергенції регіонів у контексті забезпечення конвергентності освітніх процесів є їхня адаптивність - здатність регіонів реагувати на вимоги і нові можливості, які створюють новітні технології, нововведення, сучасний менеджмент.

Реалізація політики конвергенції соціально-економічного розвитку регіонів України безпосередньо пов'язана з розробкою регіональними органами влади, місцевими органами самоврядування науково обґрунтованої стратегії інноваційної реструктуризації економіки регіонів. Така стратегія повинна базуватися на таких принципах, як легітимність, об'єктивність, цілеспрямованість, ефективність та безперервність, використання мето- 
дів прямого стимулювання інноваційного розвитку [6].

Процеси об'єднання потоків розрізнених академічних департаментів, а також самостійних організацій профільної галузі забезпечують гнучке й оперативне генерування конвергентного професійно спрямованого освітнього контенту, зосередженого на розвитку культурно-освітніх та науково-дослідних якостей здобувачів освітніх послуг.

Основна перевага конвергентної освітньої системи порівняно із традиційною полягає в подоланні монополії окремих дисциплін, що сприяє формуванню у студентів ставлення до просторово-економічних систем як до рівноцінного компонента професійної діяльності та підготовки до неї, забезпечує професійно орієнтоване навчання в університеті [3].

Відмітною рисою конвергентної освіти $€$ пріоритетна увага до діяльнісного аспекту формування компетенцій, що відповідає сутності професійної компетентності, яка характеризується готовністю і здатністю до діяльності. Його особливістю є дотримання логіки розвитку сучасної науки - парадигма розвитку науки наприкінці XX ст. змінилася від вивчення того, як влаштований світ, до того, щоб цілеспрямовано створювати якісь його елементи у XXI ст. [11].

Упровадження сучасного управління в закладах вищої освіти в умовах європейської конвергенції можливе за дотримання низки умов:

- соціально-педагогічних, що передбачають дотримання принципів демократизації та гуманізації освітнього процесу під час управління ним. Забезпечення необхідних передумов для творчого зростання педагогічного та студентського колективів, представників адміністративного апарату з метою подальшого залучення їх до проведення експериментально-дослідницької діяльності;

- психолого-педагогічних, що орієнтовані на забезпечення постійного швидкісного інформування співробітників із науково-педагогічних питань, участі закладу в інноваційних проєктах і асоціаціях, інституційного забезпечення освітнього процесу та зростання кваліфікаційного рівня суб'єктів освітнього процесу, формування у працівників ЗВО інноваційної культури;

- організаційно-педагогічних, які спрямовані на забезпечення фінансування діяльності закладу в євроінтеграційному руслі розвитку та розроблення системи стимулювання для реалізації освітніх пріоритетів завдяки встановленню системних зв'язків з іншими україн- ськими та європейськими науковими установами й організаціями.

Уважаємо за доцільне згрупувати чинники готовності до професійної діяльності майбутніх викладачів вищої школи в умовах інтернаціоналізації європейського освітнього простору в чотири компоненти, на вдосконалення яких і повинна бути орієнтована система професійної освіти. Це насамперед психофізичні властивості майбутнього фахівця, які забезпечують його працездатність і формують професійну спрямованість. Другим компонентом $€$ інтелектуальні якості особистості, пов'язані з особливостями сприйняття та засвоєння навчального матеріалу (сприйнятливість, пам'ять, рухливість нервових процесів, емоційність); третім є рівень теоретичної підготовленості та запас практичних умінь і навичок; четвертим компонентом є мотиви й цінності професійної діяльності, інтереси й життєві ідеали особистості. Варто зазначити, що професійна готовність може по-різному залежати від стану окремого компонента, оцінювання яких повинно проводитись у якісних, педагогічних категоріях - критеріях готовності до професійної діяльності.

Конвергентна стратегія професійної підготовки стає можливою за умови поєднання нормативної організації освітнього процесу й ініціативної освітньої діяльності студентів. У процесі конвергентної освіти виникає потреба в інноваційному оновленні всіх складових частин навчального процесу в університеті. Забезпечення ефективності навчання досягається за допомогою надання психолого-педагогічної підтримки і забезпечення методичного супроводу студентів у процесі формування професійно орієнтованої компетенції.

Результати здійснення конвергентної стратегії виглядають більш привабливими порівняно з нинішньою системою навчання, оскільки формування професійно-методичної компетентності водночас має своєю метою усвідомлення культурної місії, що є внутрішнім стимулом для вдосконалення всіх компонентів компетенції, підвищення якості навчання.

Висновки. Конвергентність освіти має потужний вплив на якість підготовки майбутніх фахівців. В умовах цілеспрямованої орієнтації освітньої системи на європейську інтеграцію варто відзначити, що конвергентність заснована на формуванні компетентностей, важливих для майбутніх фахівців. Проте водночас вивчення конвергентності в наукових працях представлено досить поверхнево, що надає можливість для широкого кола детальних досліджень у розрізі різних аспектів. 


\section{ПУБЛІЧНЕ УПРАВЛІННЯ І АДМІНІСТРУВАННЯ В УКРАЇНІ}

\section{ЛITEPATУРA:}

1. Алексеева И.Ю. Информационная компетентность, естественный интеллект и НБИКС-революция. Информационное общество. 2012. № 5. С. 9-15.

2. Деев М.В., Кравец А.Г., Финогеев А.Г. Конвергентная модель инорормационно-образовательной среды для синхронизации образовательных ресурсов и программ с уровнями квалисрикации специалистов. Фундаментальные исследования. 2017. № 12. C. $52-57$.

3. Денисюк Л.В. Конвергентна стратегія методичної підготовки викладача іноземної мови університету. Науковий огляд. 2020. № 4 (67). С. 67-77.

4. Державне управління реформуванням вищої освіти в Україні : монограсрія. Харків : НУЦЗУ, 2020. $285 \mathrm{c}$.

5. Лубский А.В. Междисциплинарные научные исследования : когнитивная «мода» или социальный «вызов». Социологические исследования. 2015. № 10. С. 3-11.

6. Писаренко С.М. Інноваційне забезпечення конвергентності соціально-економічного розвитку регіонів України. Соціально-економічні проблеми сучасного періоду України. 2014. № 3. C. 86-95.
7. Сулаєва Н.В. Конвергентність різних видів освіти студентів психолого-педагогічного фракультету Полтавського національного педагогічного університету імені В.Г. Короленка. Естетика і етика педагогічної дії. Київ ; Полтава. 2018. № 17. С. 119-127.

8. Управління рівнем дивергенції та конвергенції в освіті. Економіка і організація управління. 2018. № 2. C. 14-21.

9. Фещенко Т.С., Шестакова Л.А. Конвергентный подход в школьном образовании - новые возможности для будущего. URL: https://research-journal. org/ pedagogy/konvergentnyjpodxod-v-shkolnomobrazovanii-novye-vozmozhnosti-dlya-budushhego/ (дата звернення: 16.07.2020).

10. Філософрія інтеграції : монографрія. Ужгород : ЗакДУ, 2011. 544 с.

11. Bainbridge M.S., Roco M.C. Managing nanobio infocognoinnovations: converging technologies in society. Springer. 2005.

12. Challenges and Opportunities for Innovation through Technology : The Convergence of Technologies. Directorate for science, technology and innovation of the Committee for scientific and technological policy of the Organization for Economic Cooperation and Development. 2014. Sept. 39 p. 